\title{
Cell transplantation and clinical reality: Kuwait experience in persons with spinal cord injury
}

\author{
S. Al Kandari ${ }^{1}$ - L. Prasad ${ }^{1}$ • M. Al Kandari ${ }^{1}$ - U. Ramachandran ${ }^{1}$ - A. Krassioukov ${ }^{2}$
}

Received: 13 October 2017 / Revised: 23 January 2018 / Accepted: 4 February 2018 / Published online: 22 February 2018

(c) International Spinal Cord Society 2018

\begin{abstract}
Study design Retrospective observational.

Objectives To compare objective (neurological examination) and subjective (patients perception) recovery in patients with spinal cord injury (SCI) who chose to undergo cell transplantation therapies (CTT) outside of clinical trials abroad.

Setting Physical Medicine and Rehabilitation Hospital, Kuwait.

Methods Nine patients with SCI who had undergone CTT outside Kuwait were identified and their neurological pretransplantation evaluation according the International Standards for Neurological Classification of SCI (ISNCSCI) was collected from hospital records. Post transplantation ISNCSCI examination was conducted during follow-up visits and scores were completed between pre and post CTT. In addition to the ISNCSCI evaluation, change in disability status, and patient's perception of improvement after stem cell transplantation were examined.

Results Overall, 8 males and 1 female with chronic SCI underwent CTT $(42 \pm 38.2$ months post SCI $)$ in various centers (China, Egypt, Germany, India, and Iran). On follow-up post CTT assessment (89.2 \pm 36 months post SCI), 55.5\% of individuals reported perceived improvement as follows: increased deep tissue sensation below the injury (100\%) or increase in bladder sensation $(11.1 \%)$. Objective examination after CTT revealed that none of the examined individuals demonstrated improvement in their motor scores or neurological level of SCI.
\end{abstract}

Conclusion We were not able to objectively document clinically useful improvements in sensorimotor, autonomic, or functional status in individuals after CTT.

\section{Introduction}

Spinal cord injury (SCI) is a devastating event which compromises the motor, sensory, and autonomic functions. Despite significant progress in the management and care of individuals with SCI presently there is still no effective treatment available to restore connectivity within the fragile neuronal spinal cord circuits. Cell transplantation therapies

S. Al Kandari

kandari77@hotmail.com

$\triangle$ A. Krassioukov

krassioukov@icord.org

1 Physical Medicine and Rehabilitation Hospital, Ministry of Health, Andalous, Kuwait

2 ICORD, Department of Medicine, University of British Columbia, and GF Strong Rehabilitation Centre, Vancouver Costal Health, Vancouver, BC, Canada
(CTT) may possibly hold promise for spinal cord repair and regeneration but still remains in the experimental stages [1].

During the last decade, the international scientific community made significant progress and multiple animal studies were conducted demonstrating the potential effects of CTT on recovery of motor, sensory and autonomic functions [2-5]. However, as evident from the one of the latest detailed reviews of the potential outcomes of these therapies in pre-clinical studies, "the results have generally not been very promising" [6]. At the same time, a joint international effort was put into examining the safety of the newest CTT and development of recommendations and standards for conducting the clinical trials with the use of CTT following SCI [7-9]. Presently, despite significant scientific efforts, human studies have not yet conclusively demonstrated the efficacy of treatment with CTT.

However, a significant number of individuals with chronic SCI who completed their rehabilitation continue to explore any potential therapy that promises a "cure for paralysis". Many of these individuals are very proactive 
Table 1 Demographic of participants

\begin{tabular}{lllllll}
\hline Patient & Gender & $\begin{array}{l}\text { Age at } \\
\text { injury }\end{array}$ & $\begin{array}{l}\text { Date of } \\
\text { injury }\end{array}$ & $\begin{array}{l}\text { Cause and level } \\
\text { of injury }\end{array}$ & $\begin{array}{l}\text { Neurological level and } \\
\text { AIS }\end{array}$ & $\begin{array}{l}\text { Initial } \\
\text { management }\end{array}$ \\
\hline$\# 1$ & Male & 20 & 2005 & MVA & T10 A & Surgical \\
$\# 2$ & Male & 20 & 1999 & MVA & C3 C & Surgical \\
$\# 3$ & Male & 24 & 2000 & MVA & T6 A & Surgical \\
$\# 4$ & Male & 21 & 1999 & MVA & C7 A & Surgical \\
$\# 5$ & Male & 22 & 2010 & MVA & T8 A & Surgical \\
$\# 6$ & Male & 25 & 2015 & MVA & C8 A & Surgical \\
$\# 7$ & Male & 21 & 2004 & MVA & T5 B & Surgical \\
$\# 8$ & Male & 28 & 2009 & MVA & T6 C & Surgical \\
\hline 9 & Female & 29 & 2011 & MVA &
\end{tabular}

AIS American Spinal Injury Association Impairment scale, $M V A$ Motor vehicle accident, $C$ cervical, $T$ thoracic

with their decisions and travel around the world in order to participate in these frequently unproven treatments. It is crucial for the medical community to be aware about the present state of CTT that is performed outside of the welldesigned clinical trials and potential outcomes of these treatments. In this study, we examined the experience of a large tertiary rehabilitation hospital in Kuwait with potential outcomes and personal perceptions of SCI patients on the benefits of CTT performed outside of Kuwait.

\section{Methods}

\section{Participants}

The protocol for this study was approved by the Ethics committee of the Kuwait Rehabilitation Hospital. Patients with chronic SCI who underwent CTT treatment and were under care and followed up at the Physical Medicine and Rehabilitation Hospital in Kuwait were identified. All these patients had undergone CTT in various international centers in China, Egypt, Germany, India, and Iran. All of these individuals had to pay out of their pocket for the performed procedures and therefore were not part of approved clinical trials. Only patients who were examined prior to CTT and returned for further follow-up and management within the Kuwait Rehabilitation Hospital were included into the study. Considering the heterogeneity of the cells transplanted between all individuals, our use of the CTT term describes any type of cells that were introduced in various patients as a potential treatment for SCI (e.g., embryonic stem cells, Schwann cells, autologous bone marrow-derived cells or peripheral blood-derived cells, and others).

Patient medical records were retrieved and retrospective data of their neurological level including bladder/bowel status, and American Spinal Injury Association (ASIA) Impairment Scale (AIS) conducted by the same physician according to the Internationally Standards for neurological classification of SCI (ISNCSCI) [10] prior to CTT were obtained. The post CTT neurological status (AIS score) and any neurological improvement was established following return to Kuwait and examination by the primary treating physiatrist as well as an independent examiner. In addition to AIS score, data on changes in pain, bladder, bowel, and sexual functions were collected. Finally, the patient's perceived improvement in their physical and functional status after the CTT intervention was also documented.

\section{Results}

\section{Demographic and treatments received}

A total of nine individuals with SCI were included into the study. There were 8 males and 1 female between the ages of 20 to 29 years (mean age 23.33 years) at the time of injury and they all sustained SCI as a result of motor vehicle accident (MVA), Table 1. The time duration between the onset of SCI and first CTT was $\sim 2 \pm 38.2$ months. Our nine participants' received a total of 14 CTT procedures. Four individuals (44.4\%) underwent multiple CTT procedures. One individual (case \#3) underwent four CTT procedures in China over a 4 year period-two treatments with fetal stem cells, one with "nerve cells" and one with olfactory cells as per patient reports. Two individuals, in addition to CTT, also received autologous nerve graft implantation to the site of injury. One of these individuals also received intravenous injection of an unknown substance. Finally, the last individual received CTT (autologous bone marrow-derived cells) at two different centers (Table 2). It was evident from our participant interviews that $55.5 \%$ of the patients had a poor understanding of the procedures and nature of transplanted cells. Only 4 individuals had received discharge reports for the procedures (29\%). Two of these subjects (\#1 
Table 2 Details on cell transplantation therapy

\begin{tabular}{|c|c|c|c|c|c|}
\hline Patient & $\begin{array}{l}\text { Date of CTT } \\
\text { procedure }\end{array}$ & $\begin{array}{l}\text { Source of } \\
\text { information }^{\text {a }}\end{array}$ & $\begin{array}{l}\text { Details of CTT (cells type; rout of administration; } \\
\text { volume) }\end{array}$ & $\begin{array}{l}\text { Time post SCI } \\
\text { (years) }\end{array}$ & $\begin{array}{l}\text { Cost of CTT } \\
(\$ \text { USD })^{\mathrm{b}}\end{array}$ \\
\hline \multirow[t]{2}{*}{ \# 1} & 2009 & PR & "Cells from my leg nerve" & 4 & 12,000 \\
\hline & 2013 & DS & $\begin{array}{l}\text { Autologous bone marrow; } 2 \mathrm{ml} \text { of cell suspension was } \\
\text { injected intrathecally }\end{array}$ & 8 & 15,000 \\
\hline \# 2 & 2008 & PR & "Blood cells" & 9 & 9000 \\
\hline \multirow[t]{4}{*}{ \# 3} & 2006 & PR & "Embryonic cells" & 6 & 20,000 \\
\hline & 2007 & PR & "Embryonic cells" & 7 & 10,000 \\
\hline & 2008 & PR & "Cells from my leg nerve" & 8 & 10,000 \\
\hline & 2009 & PR & "Cells from my nose" & 9 & 10,000 \\
\hline \# 4 & 2006 & DS & $\begin{array}{l}\text { Autologous olfactory glial cells; } 100 \mu \mathrm{l} \text { containing } \\
1,000,000 \text { cells injected to the C6 spinal cord segment }\end{array}$ & 7 & 30,000 \\
\hline \multirow[t]{2}{*}{ \# 5} & 2011 & PR & "Cells from my bones"; multiple intrathecal injections & 1 & 120,000 \\
\hline & 2012 & PR & "Cells from my bones" & 2 & 15,000 \\
\hline \# 6 & 2015 & $\mathrm{PR}+\mathrm{DS}$ & $\begin{array}{l}\text { Mixture of the autologous cells from peripheral nerve } \\
\text { and embryonic stem cells were injected intrathecally }\end{array}$ & 0.3 & 42,000 \\
\hline \# 7 & 2006 & PR & "Cells from my nose" & 2 & 42,000 \\
\hline \# 8 & 2010 & PR & "Cells from my bones"; multiple injections & 1 & 570 \\
\hline \# 9 & 2012 & $\mathrm{PR}+\mathrm{DS}+\mathrm{RRL}$ & $\begin{array}{l}\text { Fetal stem cells; } 5 \text { million cells injected at the site of } \\
\text { injury. }\end{array}$ & 0.8 & 45,000 \\
\hline
\end{tabular}

CTT cell transplantation therapy

a The source of information regarding the CTT: $P R$ patient's own report based on verbal communication with medical professionals at time of treatment. In majority of cases patients did not fully understand the type of cells that were injected and here we are using the "terms" used by patients; $D S$ discharge summary provided at the time of discharge from the center; $R R L$ response to Request Letter by the treatment center following our letter of request for additional information

${ }^{\mathrm{b}}$ Cost of the procedure based on patient's reports

and 4) had discharge summaries that included details of their CTT, and only in two cases (case \#4 and 9) we were able to obtain a clear description of the type, volume of transplanted cells and the site of implantation (Table 2).

\section{Neurological and functional outcomes}

Comparison of neurological examination before and after CTT (average time post CTT 91.2 \pm 36 months) revealed that none of the individuals in our study demonstrated any improvement in motor score (Table 3). Subject \#4 (C7 AIS A) 6 months after CTT developed flicker of finger flexion at the proximal interphalangeal joint of the ring, middle, and index fingers of the right hand (flexor digitorum superficialis). However, weak contraction of the muscle was noted even prior to CTT. The visible movement of the fingers 6 months post CTT could be explained by the intensive physical therapy program which he underwent after the procedure. He also presented with newly developed neuropathic sensations after CTT in his perianal region and left leg 4 years after CTT. Subject \#5 showed no change in his neurological level of T8, but his sensory scores improved from 112 to 131 (up to T12 dermatome)Fig 1 . However, he perceived significant improvement in subjective sensation up to L3 level within a day following CTT.
Subject \#3, \#6 and \#9 also had minor improvements in sensory scores but no change in motor scores or neurological levels.

\section{Patient's perceived benefits}

Four of the participants reported that they did not receive any benefits from the CTT (Table 3). None of the participants noted functional motor improvements following CTT. However, the majority of participants (5 individuals, 55.5\% reported some perceived improvements in sensation. But in two of these individuals, the reported sensory changes following CTT were neuropathic in nature (e.g., the described presence of hot sensation). One individual (subject \#1; $11.1 \%$ ) also reported an increase in bladder sensation, improvement in sexual function (improved ejaculation and erection), and improvement in trunk control. However, there was no change in his bladder function or sexual health management following CTT.

\section{Discussion}

On the basis of our experience at the Kuwait Rehabilitation Center with follow-up of individuals with chronic SCI who 
Table 3 Perceived benefits by the SCI patients post cell transplantation therapy

\begin{tabular}{|c|c|c|c|c|c|}
\hline \multirow{2}{*}{$\begin{array}{l}\text { Subject } \\
\text { ID \# }\end{array}$} & \multirow{2}{*}{$\begin{array}{l}\text { AIS and motor/ } \\
\text { sensory scores } \\
\text { before CTT }\end{array}$} & \multicolumn{3}{|c|}{ Perceived benefits } & \multirow{2}{*}{$\begin{array}{l}\text { AIS and motor/ } \\
\text { sensory scores } \\
\text { after CTT }\end{array}$} \\
\hline & & Motor & Sensory & Others & \\
\hline \# 1 & $\begin{array}{l}\text { T10 AIS A } \\
\text { MS }=50 \\
\text { LTS }=70 \\
\text { PPS }=70\end{array}$ & Nil & $\begin{array}{l}\text { Improvement in L1 and } \\
\text { L2 dermatome (hot } \\
\text { sensation) }\end{array}$ & $\begin{array}{l}\text { Increase of bladder } \\
\text { sensation, sexual } \\
\text { function and trunk } \\
\text { balance }\end{array}$ & $\begin{array}{l}\text { T10 AIS A } \\
\text { MS }=50 \\
\text { LTS }=70 \\
\text { PPS }=70\end{array}$ \\
\hline \# 2 & $\begin{array}{l}\text { C5 AIS C } \\
\text { MS }=22 \\
\text { LTS }=35 \\
\text { PPS }=10\end{array}$ & Nil & Nil & Nil & $\begin{array}{l}\text { C5 AIS C } \\
\text { MS }=22 \\
\text { LTS }=35 \\
\text { PPS }=10\end{array}$ \\
\hline \# 3 & $\begin{array}{l}\text { T6 AIS A } \\
\text { MS }=50 \\
\text { LTS }=53 \\
\text { PPS }=53\end{array}$ & Nil & $\begin{array}{l}\text { Improved deep sensation: } \\
\text { "awareness" of the legs } \\
\text { when seated }\end{array}$ & Nil & $\begin{array}{l}\text { T6 AIS A } \\
\text { MS }=50 \\
\text { LTS }=58 \\
\text { PPS }=58\end{array}$ \\
\hline \# 4 & $\begin{array}{l}\text { C7 AIS A } \\
\text { MS }=27 \\
\text { LTS }=29 \\
\text { PPS }=20\end{array}$ & Nil & $\begin{array}{l}\text { Improvement in deep } \\
\text { sensation in lower limbs }\end{array}$ & Nil & $\begin{array}{l}\text { C7 AIS A } \\
\text { MS }=27 \\
\text { LTS }=24 \\
\text { PPS }=20\end{array}$ \\
\hline \# 5 & $\begin{array}{l}\text { T8 AIS A } \\
\text { MS }=50 \\
\text { LTS }=56 \\
\text { PPS }=56\end{array}$ & Nil & $\begin{array}{l}\text { Improved sensation in } \\
\text { legs }\end{array}$ & Nil & $\begin{array}{l}\text { T8 AIS A } \\
\text { MS }=50 \\
\text { LTS }=69 \\
\text { PPS }=62\end{array}$ \\
\hline \# 6 & $\begin{array}{l}\text { T8 AIS A } \\
\text { MS }=50 \\
\text { LTS }=66 \\
\text { PPS }=60\end{array}$ & Nil & Nil & Nil & $\begin{array}{l}\text { T8 AIS A } \\
\text { MS }=50 \\
\text { LTS }=69 \\
\text { PPS }=62\end{array}$ \\
\hline \# 7 & $\begin{array}{l}\text { C8 AIS A } \\
\text { MS }=42 \\
\text { LTS }=20 \\
\text { PPS }=20\end{array}$ & Nil & Nil & Nil & $\begin{array}{l}\text { C8 AIS A } \\
\text { MS }=42 \\
\text { LTS }=20 \\
\text { PPS }=20\end{array}$ \\
\hline \# 8 & $\begin{array}{l}\text { T5 AIS B } \\
\text { MS }=50 \\
\text { LTS }=105 \\
\text { PPS }=51\end{array}$ & Nil & Nil & Nil & $\begin{array}{l}\text { T5 AIS B } \\
\text { MS }=50 \\
\text { LTS }=105 \\
\text { PPS }=51\end{array}$ \\
\hline \# 9 & $\begin{array}{l}\text { T5 AIS C } \\
\text { MS }=56 \\
\text { LTS }=67 \\
\text { PPS }=55\end{array}$ & Nil & $\begin{array}{l}\text { Improved sensation in the } \\
\text { trunk and legs }\end{array}$ & Nil & $\begin{array}{l}\text { T5 AIS C } \\
\text { MS }=56 \\
\text { LTS }=86 \\
\text { PPS }=58\end{array}$ \\
\hline
\end{tabular}

AIS American Spinal Injury Association Impairment Scale, MS motor score, LTS light touch score, PPS pin-prick score

underwent CTT abroad and outside of approved clinical trials they unequivocally demonstrated a lack of functional motor recovery. Subject \#3 had minimal improvement in sensory scores after CTT performed 6 years post SCI. Subject \#5 who had CTT done 1 year after SCI showed improvement in sensory scores. Subject \#6 who did CTT 3 months post SCI showed minimal increase in sensory scores which is expected as part of the natural recovery. The greatest change in scores was seen in subject \#9 who underwent CTT within a year post SCI. However, she was AIS $\mathrm{C}$ at the time of injury and was expected to improve spontaneously to some extent. On the basis of analysis of natural progression of recovery following SCI, it is generally agreed that the greatest gains typically occur in the first 6 months, with majority of recovery complete by 12 months post injury. However, additional recovery and small improvements have been seen up to 18 months post SCI [11, 12].

Present literature evidence is inconsistent with respect to potential functional recovery and benefits of various CTT among individuals with chronic SCI. One of the earliest reports by Dobkin et al. [13] who evaluated seven individuals with chronic SCI who underwent CTT in Beijing, China, documented that individuals who received these treatments have encountered serious medical complications and there was no clinically useful sensorimotor, disability, or autonomic improvements. In a study by Dai et al. [14] from China, the efficacy of autologous bone marrow 


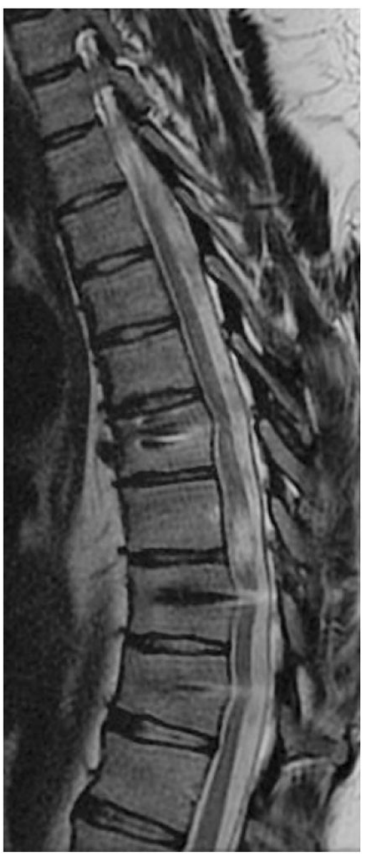

(A)

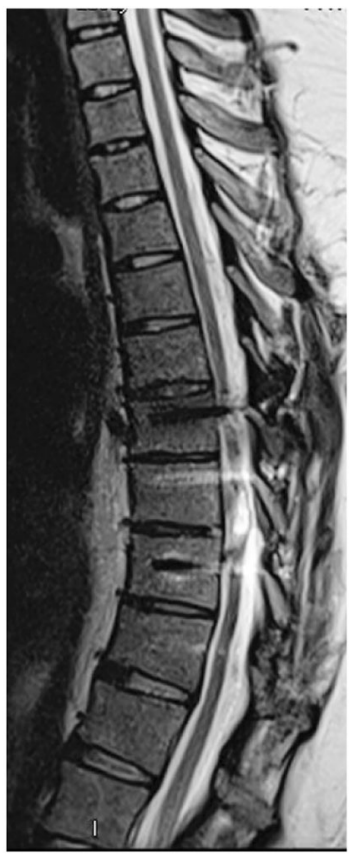

(B)
Fig. 1 MRI thoracic spinal cord post CTT in subject \#5. a MRI performed in 2013, 2 years post CTT shows cystic changes in the cord opposite at T9/10 level. b MRI performed in 2017, 5 years following CTT. The cystic lesion within the spinal cord shows no change in size. Metal artifacts from the spinal fixation are seen in both images

mesenchymal stem cells in individuals with chronic complete SCI (range 18 to 74 months post injury) was reported. Among 20 individuals who received CTT, 10 participants showed significant clinical improvement in terms of motor, light touch, and pin-prick sensorium and a decrease in residual urine volumes, whereas 9 patients showed changes in AIS grade. In a study by Yazdani et al. [15] from Iran, 8 individuals with chronic complete SCI (range 13-63 months post injury) received treatments with a combination of autologous bone marrow mesenchymal stromal cell and Schwann cell directly into the injury site. The investigators reported that these individuals had negligible improvement in sensory scores and no improvement in motor scores. Finally, in a study by Mendonca et al. [16] from Brazil, 14 subjects with chronic traumatic SCI (with at least 6 months post injury) received autologous bone marrow-derived stem cells. The investigators reported improvements in touch sensation in all participants, whereas 8 subjects exhibited lower limb motor function gains. Experimental studies have shown that CTT performed in the acute and sub-acute phases of SCI are typically associated with better evidence of locomotor recovery compared to procedures performed in chronic phases [17]. This indicates that the therapeutic window for this type of treatment may be limited to the early post injury period [18].
However, this also could coincide with the natural progression and recovery following the SCI [12].

Although none of the participant reported any complications following CTT, we were unable to document any benefit in sensory-motor or autonomic functions following CTT. Interestingly, the majority of subjects in our study who reported perceived improvement in their sensory functions were mostly describing an increase in their neuropathic sensations.

We would also like to acknowledge numerous limitations of this study, including the retrospective nature and the fact that in the significant number of procedures the crucial information of the nature of CTT was missing (79\% of procedures did not have any information regarding nature of the transplanted cells). However, the aforementioned lack of available information on CTT in these cases provides crucial insight into the challenges that clinicians face when following-up and managing patients who have made the decision and became recipients of unknown or poorly defined therapies.

\section{Conclusion}

We were unable to objectively document any clinically useful neurological recovery or functional ability after CTT among the participants in our study who received these therapies abroad. Furthermore, in $60 \%$ of individuals who reported "improved" sensation following CTT, the "new" sensations were neuropathic in nature. Many of the centers did not provide sufficient documentation or follow-up to the recipients of CTT. Despite the existence of numerous international recommendations on cell transplantation, we were unable to see any evidence that the offered treatments followed any valid clinical trial protocols. As the cost related to CTT treatments and care after the surgery are exorbitant, individuals with SCI who undertake these mostly unproven interventions, are not only left frustrated and disappointed with the results, but they and their families are also subject to significant financial losses. Hence, it is our recommendation that medical professionals who are involved in the care of individuals with SCI should caution those planning to undergo CTT regarding the experimental nature of the treatment and its limited potential benefits. Individuals and clinicians should learn more about the treatment centers, nature of the procedure, the cells to be transplanted, and if this intervention is a part of a clinical trial (in this case participants would not pay for the proposed treatments). The research team of this study would like to emphasize that CTT should be done as part of an approved and well-designed clinical trial, conducted at recognized institutions to ensure that international standards 
and guidelines are followed that will safeguard the welfare of the patients.

\section{Data archiving}

There were no data to deposit.

\section{Compliance with ethical standards}

Conflict of interest The authors declare that they have no conflict of interest.

\section{References}

1. Blight A, Curt A, Ditunno JF, Dobkin B, Ellaway P, Fawcett J, et al. Position statement on the sale of unproven cellular therapies for spinal cord injury: the international campaign for cures of spinal cord injury paralysis. Spinal Cord. 2009;47:713-4.

2. Cao Q, Xu XM, Devries WH, Enzmann GU, Ping P, Tsoulfas P, et al. Functional recovery in traumatic spinal cord injury after transplantation of multineurotrophin-expressing glial-restricted precursor cells. J Neurosci. 2005;25:6947-57.

3. Hou S, Tom VJ, Graham L, Lu P, Blesch A. Partial restoration of cardiovascular function by embryonic neural stem cell grafts after complete spinal cord transection. J Neurosci. 2013;33:17138-49.

4. Squair JW, West CR, Krassioukov AV. Neuroprotection, plasticity manipulation, and regenerative strategies to improve cardiovascular function following spinal cord injury. J Neurotrauma. 2015;32:609-21.

5. Yan J, Xu L, Welsh AM, Hatfield G, Hazel T, Johe K, Koliatsos VE. Extensive neuronal differentiation of human neural stem cell grafts in adult rat spinal cord. PLoS Med. 2007;4:e39.

6. Tetzlaff W, Okon EB, Karimi-Abdolrezaee S, Hill CE, Sparling JS, Plemel JR, et al. A systematic review of cellular transplantation therapies for spinal cord injury. J Neurotrauma. 2011;28:1611-82.

7. Fawcett JW, Curt A, Steeves JD, Coleman WP, Tuszynski MH, Lammertse D, et al. Guidelines for the conduct of clinical trials for spinal cord injury as developed by the ICCP panel: spontaneous recovery after spinal cord injury and statistical power needed for therapeutic clinical trials. Spinal Cord. 2007;45:190-205.
8. Lammertse D, Tuszynski MH, Steeves JD, Curt A, Fawcett JW, Rask C, et al. Guidelines for the conduct of clinical trials for spinal cord injury as developed by the ICCP panel: clinical trial design. Spinal Cord. 2007;45:232-42.

9. Levi AD, Okonkwo DO, Park P, Jenkins AL III, Kurpad SN, Parr AM, et al. Emerging safety of intramedullary transplantation of human neural stem cells in chronic cervical and thoracic spinal cord injury. Neurosurgery. 2017. https://doi.org/10.1093/neuros/ nyx 250. [Epub ahead of print]

10. Kirshblum SC, Burns SP, Biering-Sorensen F, Donovan W, Graves DE, Jha A, et al. International standards for neurological classification of spinal cord injury (revised 2011). J Spinal Cord Med. 2011;34:535-46.

11. McDonald JW, Becker D, Sadowsky CL, Conturo TE, Schultz LM. Correction addendum to: late recovery following spinal cord injury. J Neurosurg. 2002;97:405-6.

12. Steeves JD, Kramer JK, Fawcett JW, Cragg J, Lammertse DP, Blight AR, et al. Extent of spontaneous motor recovery after traumatic cervical sensorimotor complete spinal cord injury. Spinal Cord. 2011;49:257-65.

13. Dobkin BH, Curt A, Guest J. Cellular transplants in China: observational study from the largest human experiment in chronic spinal cord injury. Neurorehabil Neural Repair. 2006;20:5-13.

14. Dai G, Liu X, Zhang Z, Yang Z, Dai Y, Xu R. Transplantation of autologous bone marrow mesenchymal stem cells in the treatment of complete and chronic cervical spinal cord injury. Brain Res. 2013;1533:73-9.

15. Yazdani SO, Hafizi M, Zali AR, Atashi A, Ashrafi F, Seddighi AS, et al. Safety and possible outcome assessment of autologous Schwann cell and bone marrow mesenchymal stromal cell cotransplantation for treatment of patients with chronic spinal cord injury. Cytotherapy. 2013;15:782-91.

16. Mendonca MV, Larocca TF, de Freitas Souza BS, Villarreal CF, Silva LF, Matos AC, et al. Safety and neurological assessments after autologous transplantation of bone marrow mesenchymal stem cells in subjects with chronic spinal cord injury. Stem Cell Res Ther. 2014;5:126.

17. Keirstead HS, Nistor G, Bernal G, Totoiu M, Cloutier F, Sharp K, et al. Human embryonic stem cell-derived oligodendrocyte progenitor cell transplants remyelinate and restore locomotion after spinal cord injury. J Neurosci. 2005;25:4694-705.

18. Yousefifard M, Rahimi-Movaghar V, Nasirinezhad F, Baikpour M, Safari S, Saadat S, et al. Neural stem/progenitor cell transplantation for spinal cord injury treatment: a systematic review and meta-analysis. Neurosci. 2016;322:377-97. 